\title{
MODERN PEDAGOGICAL TECHNOLOGIES IN HIGHER EDUCATION
}

\author{
Olexander Chernenko ${ }^{1}$ \\ ${ }^{I}$ Ph.D. (Pedagogy), Associate Professor of the Department of Socio-Economic Relations, Kirovograd \\ Institute for Human Development, Kropivnitsky, Ukraine, e-mail: Chernenko_O.V.fp@i.ua, ORCID: \\ https://orcid.org/0000-0001-7012-1797
}

\begin{abstract}
The article describes the main pedagogical technologies used in higher education. Traditional and innovative pedagogical technologies of higher education are studied. Modern pedagogy is a set of theoretical and applied sciences about teaching, upbringing and education as specially organized and purposeful processes, as well as ways to improve these processes. That is why the learning process in higher education is implemented within a holistic system of organizational forms, methods and technologies of teaching, which makes it possible to form a competent specialist. The purpose of the article is to explore modern higher school pedagogy and pedagogical technologies, principles, methods on which it is based and which is guided in its activities. It is proved that pedagogical technologies include the following components: educational technologies that define the concepts of education, educational systems; learning technologies (education, management) - forms and methods of teaching; technologies in education - technical means of education; pedagogical technique that reflects the level of pedagogical skills of the teacher. Modular and developmental learning contributes to the formation of personality not only through the content, methods, forms of organization, but also through active self-education of students, which leads to greater results. Currently, there are several approaches to creating a modular system depending on the geography and content and structural features of innovation and educational experience: American and German models, Lithuanian model, Ukrainian. The variety of methods and forms of work with modular-rating pedagogical technology makes it possible to better master the theoretical and practical material, and therefore in modern higher school pedagogy, this technique is one of the first places. It is concluded that the modular technology of teaching, analysis and evaluation of students' learning activities is an important step towards the intensification and optimization of the educational process in higher education. The modular system of education requires from scientific and pedagogical workers proper psychological and pedagogical training, restructuring of organizational and methodological aspects of the educational process. Humanities education is designed to enrich the intellectual and spiritual culture of man as an active creator of material and spiritual values.
\end{abstract}

Keywords: pedagogical technologies, classification of technologies, traditional and innovative pedagogical technologies, modular-rating system of education.

JEL Classification: I0; I20

Formulas: 0; fig.: 0; tabl.: 0; bibl.: 14

Introduction. The modern period of development of society in the state, new transformations implemented in all spheres of life require the transition from educators to a qualitatively new level of pedagogical work, as there is a replacement of educational systems, teaching methods, new content, other approaches, learning technologies. The Law "On Education" states the purpose of higher education as follows: "The strategic objectives of the higher education system and its priority areas for reform are set out in the State National Program "Education" ("Ukraine of the XXI Century").

Higher school pedagogy should ensure the implementation of the following functions: educational, scientific-cognitive, motivational, transformative, predictive, 
projective, culturological, adaptive, formative-educational and formativeprofessional.

That is why recently in education there have been some changes due to the reform of higher education, which prompted the introduction of new pedagogical technologies.

Literature review. The main aspects and principles of education, which are guided by teachers of higher education, are enshrined in the legislation of Ukraine. In particular, the Constitution of Ukraine and the Law of Ukraine on Education.

Issues and problems of pedagogy in general, and higher education in particular, were studied by such researchers as V.M. Galuzinsky, M.B. Yevtukh, N. V. Kuzmina, A. M. Aleksyuk, S. S. Vitvytska, A. I. Kuzminsky, Z. N. Kurland, V. M. Nagaev, V. L. Ortynsky and others. The main principles of reforming the system of higher education, which provided for a change in approaches to teaching and educating student youth, are covered in the works of P. Talanchuk, V. Zaychuk, M. Zgurovsky, V. Kremen, S. Nikolaenko, M. Stepko; monographic researches of Y. Alekseev, O. Navrotsky, V. Yablonsky, T. Finikov are devoted to the peculiarities of formation and development of higher educational institutions of Ukraine; experimental work on the implementation of the ideas of the Bologna process in modern higher education is reflected in the works of J. Bolyubash, V. Shinkaruk, V. Grubinko; modern approaches to the education of student youth are considered by O. Robul, N. Semergey. However, even today there are many problems and unresolved issues regarding the educational system of Ukraine, pedagogy in general and pedagogical technologies of higher education.

Aims. The purpose of the article is to explore modern higher school pedagogy and pedagogical technologies, principles, methods on which it is based and which is guided in its activities.

To achieve this goal, you must solve the following tasks:

- to find out the features of the modern educational system and the specifics of higher education;

- to reveal the principles of higher school pedagogy;

- explore pedagogical technologies used in higher education;

- identify traditional and innovative pedagogical learning technologies in higher education.

Methods. The methods used in the research process relate to general scientific knowledge. Historical-geographical method for studying educational experience: American and German models, Lithuanian model, Ukrainian. The method of analysis is for a thorough study of the modular technology of training organization. Descriptive method - to generalize the classification of modern methods and technologies of teaching in higher education.

Results. The current stage of development of Ukrainian society is characterized by bringing education to the level of developed countries. Education is one of the most important strategic areas of any state, because it contains the potential for future development. As a result of the strengthening of democratic ideas in the modern world, there is a need to bring Ukrainian education in line with the requirements and 
demands of today. Accordingly, the reaction of higher school teachers was a largescale deployment of the innovation process, testing and implementation of new concepts and technologies in the theory and practice of modern education. "At the turn of the millennium, a new system of higher education is being created in Ukraine, focused on entering the world educational space. This process is accompanied by significant changes in the pedagogical theory and practice of the educational process of the university. There is a change in the educational paradigm, a new content is proposed, other approaches, a different pedagogical mentality" [3, p. 146] However, this does not mean that modern educators have completely departed from traditional pedagogical learning technologies. Because in the conditions of informatization and globalization of modern society it is necessary to bring up a competent specialist.

Modern pedagogy is a set of theoretical and applied sciences about teaching, upbringing and education as specially organized and purposeful processes, as well as ways to improve these processes. That is why the learning process in higher education is implemented within a holistic system of organizational forms, methods and technologies of teaching, which makes it possible to form a competent specialist.

Recently, the terms "technology", "pedagogical technology", "learning technology", "educational technology", "learning technology", "technology in education" are widely used in science and education, and therefore have many formulations, depending on how the authors present the structure and component of the educational process.

This is emphasized by S. Sysoyev in the work "Fundamentals of pedagogical creativity", "A special role in the implementation of these tasks belongs to pedagogical technologies, which are now introduced into the system of continuing education and serve, creative and spiritual development, and the needs of society for personal, professional and social development of man" [13, pp. 86-87].

The concept of "pedagogical technology" is not new to pedagogy, it is known since the 20s of the twentieth century, but its interpretation in the twentieth century has changed. Scientific research in the direction of optimization and improvement of the organization of educational process at various levels of education, including higher education, testifies to essential transformation of the term "pedagogical technology" - from "technology in education" to "technological education", and then to "Pedagogical technology" [3, p. 150].

Pedagogical technologies are an organizational principle that launches into action and directs in the necessary direction the creative forces of the bearers of scientific knowledge and pedagogical experience" [13, pp. 86-87].

To date, there are more than 300 definitions of "pedagogical technology". All these definitions are expressed differently in relation to the system of principles, techniques and methods used in the learning process. The most common are the following interpretations of the concept.

"Pedagogical technology is a well-thought-out model of pedagogical activity in the design, organization and conduct of the educational process with unconditional provision of comfortable conditions for students and teachers" [12, p. 27]. 
"Pedagogical technology is a systematic method of creating, applying and defining the whole process of teaching and learning, taking into account technical and human resources in their interaction, which aims to optimize forms of learning (UNESCO)" [3, p. 150-151].

S. P. Maksymyuk acquires a different interpretation of the term "pedagogical technology" in the work "Pedagogy", where it is stated that "pedagogical technology is a pedagogically and economically justified process of achieving guaranteed, potentially reproducible, planned pedagogical results, which includes the formation of students' knowledge and skills specially processed content and which is implemented strictly on the basis of NOP and step-by-step testing" [10, p. 602].

Summarizing all the definitions, we conclude that pedagogical technologies include the following components:

- educational technologies that define the concepts of education, educational systems. At the present stage, it is a humanistic concept of education.

- learning technologies (education, management) - forms and methods of teaching;

- technologies in education - technical means of education;

- pedagogical technique that reflects the level of pedagogical skills of the teacher.

The most thorough interpretation of the term is given in the work of S. S. Vitvytska, who argues that pedagogical technology is "a system of the most rational ways to achieve the pedagogical goal, the scientific organization of the educational process, which determines the most rational and effective ways to achieve the ultimate educational goal "cultural goals". [3, p. 151].

Taking into account all these factors [9-14], modern pedagogical technologies of universities must meet the following criteria:

- conceptuality - a clear definition of philosophical, psychological, didactic, social, etc. concepts that define educational goals. All these elements are disclosed in educational sources, such as the National Doctrine of Education of Ukraine in the XXI century, the State National Program "Education" ("Ukraine of the XXI century"), the Law of Ukraine "On Amendments to the Law of the USSR "On Education", The Law on Higher Education, etc.;

- systematic - clear ordering of all pedagogical technologies of the university;

- logic, integrity, completeness;

- manageability - purposefulness of the learning process, means and methods in order to achieve optimal results;

- efficiency - the selection and use of the most appropriate methods and tools of learning to achieve results;

- synthesis of traditional and innovative components, pedagogical science and practice.

In modern domestic and world pedagogical theory and practice there are many variants of pedagogical technologies and almost all of them are used in the system of higher education. So there are the following classifications:

- classification of teaching methods: by the level of activity of students (E. Y. Golant) - passive, active;

- by source of knowledge - verbal, visual, practical; 
- for didactic purposes (M. A. Danilov, B. P. Yesipov);

- by the nature of cognitive activity (I. Y. Lerner, M. N. Skatkin).

The most recognized classification of pedagogical technologies today is the classification of G. K. Selevko, who classifies all pedagogical technologies:

- by level of application - general pedagogical, part-subject, branch, local, modular, narrowly methodical;

- on a philosophical basis - materialism, idealism, dialectics, metaphysics, scientism, natural correspondence, humanism, antihumanism, anthroposophy, theosophy, pragmatism, existentialism;

- by the leading factor of psychological development - biogenic, sociogenic, psychogenic, idealistic;

- by focusing on personal structures - information - ZUN, operational - COURT, self-development - CYM, formation - SEN, formation - SDP, heuristic;

- by the nature of content and structure - educational, educational, secular, religious, general, professional, humanistic, technocratic, monotechnology, polytechnology, penetrating technologies;

- by organizational forms - classroom, alternative, academic, club, individual, group, collective way of learning, differentiated learning;

- by type of cognitive activity management - classical lecture, learning with the help of TZN, system "consultant", book learning, system of small groups, computer training, system "tutor", program management;

- approach to the child - authoritarian, didactic, anthropo-, pedocentric, personalityoriented, humane-personal, technologies of cooperation, free education, esoteric;

- by the predominant (dominant) method - dogmatic, reproductive, programmed learning, explanatory-illustrative, dialogical, developmental learning, game, problemsolving, self-developing learning, creative, informational (computer);

- in the direction of modernization of the existing traditional system - on the basis of humanization and democratization of relations, on the basis of intensification and intensification of activities, on the basis of efficiency of management organizations, on the basis of methodical and didactic reconstruction of material, nature compliance, alternative, integral technologies

- by category of students - mass technology, advanced learning, compensating, victimological, technology of work with difficult children, technology of work with gifted;

- according to the concept of assimilation - associative-reflex, developing, internalizing, behaviorist, gestalt technologies [8, p. 154].

Discussion. Each of these pedagogical technologies has a number of features, positive and negative features, so they can not all be used in high school, and the degree and extent of their use depends on many factors that must be considered when choosing any of the technologies. "At the present stage, the priority areas for improving the educational process are the development of individual forms of education, the introduction of integrated courses. development of the information base of the educational process, optimal saturation of its automated systems, research based on computer technology" [10, p. 602]. Therefore, in recent years, higher 
education institutions are increasingly resorting to the technology of modular learning, which is introduced into the educational practice of higher education as an advanced pedagogical experience and as an experimental psychological and didactic system.

Modular and developmental learning contributes to the formation of personality not only through the content, methods, forms of organization, but also through active self-education of students, which leads to greater results.

Currently, there are several approaches to creating a modular system depending on the geography and content and structural features of innovation and educational experience: American and German models, Lithuanian model, Ukrainian.

The model of such training is subject to the process of acquiring knowledge, skills and abilities in the form of perception and understanding of each new piece of information, understanding it through understanding, generalization and consolidation of knowledge, skills (ability to apply them in practice), the need for new knowledge.

At the same time, the formation of specialists "is achieved to some extent by stimulating the systematic independent work of students on the basis of structuring educational material, control and evaluation of knowledge and determining the rating of students" [9, p. 264]. The structuring of educational material is its division into logically complete parts (topics, sections), modules, the assimilation of which allows the student to achieve a certain goal.
A. Aleksyuk, V. Vonsovich,
S. Gornostaev,
I. Klyuy,
A. Kulandina, V. Semichenko, A. Furman and others interpret the concepts of module, modular training, educational module differently. In particular, V. Bodnar believes that "modular learning - the process of learning modules in a complete didactic cycle ..." [2, p. 6].

Modular technology assumes that the study of the discipline is carried out by separate modules. Accordingly, the material of the module is divided into smaller structural parts, called learning elements, which, on the one hand, are interconnected, and on the other hand, perform an independent function.

Each module covers lectures and practical classes, as well as a significant amount of independent work. The level of mastering a certain amount of program material for each module usually includes an assessment of knowledge of theoretical material, obtained through testing, classroom, tests, assessment for preparation for seminars, rapid surveys and homework (in points).

That is, the modular approach allows students to more deeply and independently master the material, because the concept of "module" covers not only the information that the student must have, but also methods and forms of direct, indirect and independent learning activities for students to master certain information.

The process of presenting the material during the modular training does not actually differ from the traditional one. The control and assessment of knowledge takes place differently: in portions, which consist of separate completed sections of the discipline. 
During the study of the section the student performs one - three tests, demonstrating a thorough knowledge of the material, skills and abilities to apply them in practice, carrying out the correction and self-assessment of their knowledge.

Positive assessment during the study of modules is taken into account in the exam, test. Students who wish to improve their knowledge and rating can take the exam for the entire course. A student who studies well and receives high marks during structural tests is eligible for exemption from examinations.

A. O. Maksymovych emphasizes, the following methods are used in modulerating training:

- information (lecture, problem lecture, story, conversation, counseling, demonstration, etc.);

- operational (algorithms, laboratory work, etc.);

- search (discussion, business game, situational tasks, brainstorming, progressive seminar, role play, defense of project fragments of the lesson or its integral structure, etc.);

- self-study (listening, reading the module, reading the text, etc.) [9, p. 267].

The variety of methods and forms of work with modular-rating pedagogical technology makes it possible to better master the theoretical and practical material, and therefore in modern higher school pedagogy, this technique is one of the first places.

Conclusions. Thus, the modular technology of organization of training, analysis and evaluation of students' educational activities is an important step towards the intensification and optimization of the educational process in higher education. But they need from scientific and pedagogical workers proper psychological and pedagogical training, restructuring of organizational and methodological aspects of the educational process.

The problem of forming a new type of educational space that adequately responds to global socio-cultural changes, and its importance in social progress is the subject of study of both scientists and practitioners - teachers. In the third millennium, there is a natural need to reform the educational system and change the emphasis in the practice of modern humanitarian training of young people. Humanities education is designed to enrich the intellectual and spiritual culture of man as an active creator of material and spiritual values.

\section{References:}

1. Aleksiuk, A. M. (1998). Pedahohika vyshchoi shkoly Ukrainy. Istoriia. Teoriia. [Pedagogy of higher education in Ukraine. History. Theory]. Kyiv: Lybid. 560 p. [In Ukraine]

2. Bondar V. (1999). Modulno-reitynhova tekhnolohiia vyvchennia navchalnoi dystsypliny (na materiali dydaktyky). [Modular-rating technology for studying the discipline (based on didactics)]. Kyiv: ABS. 1999 p. [In Ukraine]

3. Vitvytska S. S. (2006). Osnovy pedahohiky vyshchoi shkoly. [Fundamentals of higher school pedagogy]: Pidruchnyk za modulno-reitynhovoiu systemoiu navchannia dlia studentiv mahistratury. Kyiv: Tsentr navchalnoi literatury. 384 p. [In Ukraine]

4. Derzhavna natsionalna prohrama "Osvita" ("Ukraina XXI stolittia"). [State National Program "Education" ("Ukraine of the XXI century")]. Kyiv: Raiduha. 1994. 54 p. [In Ukraine] 
5. Zhorniak T. S. (2009). Vyshcha osvita Ukrainy i Bolonskyi protses. [Higher education in Ukraine and the Bologna process]: Navchalnyi posibnyk dlia samostiinoho vyvchennia dystsypliny. Donetsk: DonUEP. 72 p. [In Ukraine]

6. Kolesnichenko L. A., Borysenko L. L. (2002). Osnovy psykholohii ta pedahohiky. [Fundamentals of psychology and pedagogy]: Navch.-metod. posibnyk dlia samost. vyvch. dysts. Kyiv: KNEU. 157 p. [In Ukraine]

7. Kuzminskyi A. I. (2005). Pedahohika vyshchoi shkoly. [Pedagogy of high school]: Navchalnyi posibnyk. Kyiv: Znannia. 486 p. [In Ukraine]

8. Kurliand Z. N. (2005). Pedahohika vyshchoi shkoly. [Pedagogy of high school]. Kyiv: Znannia. 399 s. [In Ukraine]

9. Maksymovych O. (2005). Modulno-reitynhova tekhnolohiia navchannia u vyshchii shkoli. [Modularrating technology of higher education]. Visnyk Lviv. university: Ceriia pedahohika. Vyp. 19. Ch. 2. P. $263-$ 270. [In Ukraine]

10.Maksymiuk S. P. (2005). Pedahohika. [Pedagogy]: Navchalnyi posibnyk. Kyiv: Prosvita. 667 p. [In Ukraine]

11.Nahaiev V. M. (2007). Metodyka vykladannia u vyshchii shkoli. [Methods of teaching in high school]: Tsentr uchbovoi literatury. Kyiv: Prosvita. 232 p. [In Ukraine]

12. Ortynskyi V. L. (2009). Pedahohika vyshchoi shkoly. [Pedagogy of high school]. Kyiv: Tsentr uchbovoi literatury. 472 p. [In Ukraine]

13.Sysoieva S. O. (2006). Osnovy pedahohichnoi tvorchosti. [Fundamentals of pedagogical creativity]: Pidruchnyk. Kyiv: Milenium. 344 p. [In Ukraine]

14.Universytetska osvita v Ukraini ta bolonskyi protses. (2007). [University education in Ukraine and the Bologna process] / za red. A. F. Holovchuka. Kyiv: Ahrarna osvita. 83 p. [In Ukraine] 